Dr. sc. Alen Rajko, sudac i predsjednik Upravnog suda u Rijeci

\title{
SLUŽBENIČKI ODNOSI U LOKALNOJ I PODRUČNOJ (REGIONALNOJ) SAMOUPRAVI U HRVATSKOJ - REGULACIJA I OTVORENA PITANJA
}

\author{
UDK: 352 (497.5) \\ Primljeno: 15. 12. 2017. \\ Stručni rad
}

\begin{abstract}
Analizirani su glavni elementi službeničkog sustava u hrvatskoj lokalnoj i područnoj (regionalnoj) samoupravi, u kontekstu položaja lokalne samouprave u cjelini javnog sektora, pozicije upravnih tijela u strukturi lokalnih jedinica, te statusa lokalnih službenika u odnosu na cjelokupni službenički korpus i na opći radnopravni režim. Ujedno je ukazano na s time povezana otvorena pitanja u mjerodavnom zakonodavstvu i u praksi.
\end{abstract}

Ključne riječi: službenici, službenički odnosi, lokalna i područna (regionalna) samouprava

\section{UVOD}

Pojam službeničkih odnosa u Hrvatskoj označava radne odnose i status službenika u državnoj upravi te u lokalnoj i regionalnoj samoupravi.

Posebno je naglašena nužnost da osobe koje ,, različitim ovlastima vrše poslove u ime državnih tijela, tj. države imaju, u svom položaju i nadležnostima potpuno pravno uporište. (...) Treba naime, istaknuti kako su ljudi u svakoj organizaciji njezin najbitniji i nezamjenjiv element. Ljudi svojim svojstvima omogućuju ostvarivanje cilja ili ciljeva zbog kojih je organizacija ustrojena. (...) Posebno značenje pridaje se osobama koje rade u upravnim organizacijama (tijelima javne uprave) kako zbog brojnosti tih osoba i značenja nadležnosti koje ostvaruju, tako i zbog uočene ovisnosti između njihovih osobnih kvaliteta odnosno kvaliteta njihova rada i mogućnosti ostvarivanja ciljeva javne uprave“. ${ }^{1}$

Ovaj $\operatorname{rad}^{2}$ obuhvaća pozicioniranje lokalne i regionalne samouprave i njenih zaposlenika u cjelini hrvatskoga javnog sektora, glavne izvore prava na području

1 Borković, Ivo, Upravno pravo, VII. izmij. i dop. izd., Narodne novine, Zagreb, 2002., str. 261.

Dodatno o teorijskim i komparativnim normativnim pristupima ovom području, te o povijesti uzakonjivanja službeničkog statusa, v. npr. u: ibid., str. 261-272.

Usp. povijesni prikaz u: Marčetić, Gordana, Javni službenici i tranzicija, Društveno veleučilište u Zagrebu i Konrad Adenauer Stiftung, Zagreb, 2005., str. 120-138.

2 Rad je nastao na podlozi autorova izlaganja na 11. hrvatsko-francuskim upravnopravnim danima, održanima u rujnu 2017. u Splitu. 
službeničkih odnosa na lokalnoj i regionalnoj razini, posebnosti te regulacije, te neka otvorena pitanja zabilježena u stručnoj i znanstvenoj javnosti. Razmatranje se ne odnosi na radnopravni položaj lokalnih dužnosnika, tj. osoba izabranih na političke funkcije. Pored toga, ograničit ćemo se na položaj lokalnih službenika, tj. upravnih profesionalaca koji obavljaju primarnu upravnu djelatnost, ne spominjući posebno namještenike - zaposlenike u lokalnim tijelima koji obavljaju pomoćne poslove. Njihov je radnopravni položaj najvećim dijelom jednak službeničkome. ${ }^{3}$

Radi jednostavnosti izlaganja, u nastavku teksta pojmovi lokalne samouprave, lokalnih službenika, lokalnih tijela i sl., odnose se ne samo na lokalni nivo (tj. na općine i gradove) nego i na područnu/regionalnu razinu (županije). U pogledu ove teme, regulacija službeničkih odnosa jednaka je na objema razinama. Dio terminologije sadržane u tekstu normativne je naravi, dok je dio razvijen kroz stručnu i znanstvenu aktivnost.

\section{LOKALNA I PODRUČNA (REGIONALNA) SAMOUPRAVA UNUTAR HRVATSKOGA JAVNOG SEKTORA}

Tri su glavne organizacijske forme koje čine hrvatski javni sektor: državna tijela (što uključuje tijela državne uprave i druga državna tijela), lokalna samouprava, te pravne osobe s javnim ovlastima.

Osim što građanima jamči pravo na lokalnu samoupravu, uz nju Ustav Republike Hrvatske veže još jednu važnu odredbu: regulirajući diobu državne vlasti na zakonodavnu, izvršnu i sudbenu, Ustav propisuje da je (trodijelno ustrojena) državna vlast ograničena Ustavom zajamčenim pravom na lokalnu samoupravu. ${ }^{4}$ Lokalna samouprava nije, dakle, tek jedna od područnih razina organizacije javne vlasti, već predstavlja i jedan od instrumenata ograničenja državne vlasti.

Kada lokalne jedinice djeluju u okviru svojega samoupravnog djelokruga, nadzorne ovlasti državnih tijela ograničene su na nadzor ustavnosti i zakonitosti. ${ }^{5}$

U lokalnim jedinicama djeluju tri vrste tijela: predstavničko, ${ }^{6}{ }^{\text {izvršno },{ }^{7} \text { te }}$ jedno ili više upravnih tijela. ${ }^{8}$ Lokalni službenici zaposleni su u upravnim tijelima jedinice, koja nose različite nazive (odjeli, službe i dr.). ${ }^{9}$ Upravna tijela čine stalni,

3 V. čl. 2. i čl. 116. Zakona o službenicima i namještenicima u lokalnoj i područnoj (regionalnoj) samoupravi (NN 86/08 i 61/11, u nastavku teksta: ZSN).

4 Čl. 4. st. 1. i čl. 133.-138. Ustava Republike Hrvatske (NN 59/90, 135/97, 8/98 - proč. tekst, 113/00, 124/00 - proč. tekst, 28/01, 41/01 - proč. tekst, 55/01 - ispr., 76/10, 85/10 - proč. tekst i 5/14).

5 Čl. 137. Ustava Republike Hrvatske; čl. 8. Europske povelje o lokalnoj samoupravi (NN - MU 14/97 i 4/08, u nastavku teksta: Europska povelja).

6 Općinsko vijeće, gradsko vijeće, županijska skupština, Skupština Grada Zagreba.

Općinski načelnik, gradonačelnik, župan.

8 Čl. 27. - 56.c Zakona o lokalnoj i područnoj (regionalnoj) samoupravi (NN 33/01, 60/01, 129/05, 109/07, 125/08, 36/09, 150/11, 144/12, 19/13 - proč. tekst (u nastavku teksta: ZLPS).

9 Čl. 53. - čl. 56.c ZLPS-a. 
profesionalni aparat, koji - načelno - ne bi smio ovisiti o političkim promjenama u predstavničkome i izvršnom tijelu.

\section{POZICIJA LOKALNIH SLUŽBENIKA U CJELINI SLUŽBENIČKOG KORPUSA}

Najveći dio zaposlenika hrvatskoga javnog sektora može se podijeliti u dužnosnike i službenike.

Državni i lokalni dužnosnici su politički izabrane ili imenovane osobe, dok su pravosudni dužnosnici trajno imenovani profesionalci - suci i državni odvjetnici.

Radnopravni položaj dijela državnih službenika (npr. policijskih i carinskih službenika) detaljno je uređen specijalnim zakonima. Na njih se u preostalom dijelu, a na ostale službenike u cjelini, primjenjuju opći propisi o državnim službenicima. ${ }^{10}$

Javnim službenicima - u užem smislu riječi - nazivaju se zaposlenici pravnih osoba s javnim ovlastima koje obavljaju javnu službu..$^{11}$ Oni u stvari nemaju status službenika, već su u pravilu u općem režimu radnoga prava.

Nešto preciznije, zaposlenike javnog sektora u Hrvatskoj možemo podijeliti u sljedeće kategorije:

1) državni dužnosnici;

2) pravosudni dužnosnici;

3) lokalni dužnosnici;

4) pripadnici Oružanih snaga;

5) državni službenici i namještenici na koje se primarno primjenjuju odredbe posebnoga službeničkog prava;

6) državni službenici i namještenici na koje se primjenjuju isključivo odredbe općega službeničkog prava;

7) lokalni službenici i namještenici;

8) javni službenici i namještenici;

9) zaposlenici ostalih pravnih osoba s javnim ovlastima.

Prema teorijskim klasifikacijama, državni i lokalni službenici u Hrvatskoj pripadaju među redovne službenike (po kriteriju profesionalnog obavljanja službe), pragmatičke službenike (prema stupnju autonomije volje kod stvaranja službeničkog odnosa), te u pravne službenike (po mjerilu načina uređenja njihova statusa). ${ }^{12}$

10 Prvenstveno, to je Zakon o državnim službenicima (Nar. nov., br. 92/05, 142/06, 77/07, 107/07, 27/08, 122/10, 27/11, 34/11, 49/11, 57/11, 150/11, 34/12, 49/12, 37/13, 38/13 - proč. tekst, 1/15, 138/15 i 61/17).

11 U odnosu na dio javnih službenika v. npr. pojam službenika i namještenika u javnim službama u smislu čl. 1. i 2. Zakona o plaćama u javnim službama (NN 27/01 i 39/09).

12 Spomenute doktrinarne sistematizacije preuzete su prema: Borković, op. cit., str. 278-284.

Usp. karakteristična obilježja javnog službenika u: Marčetić, op. cit., str. 142-144. 


\section{SLUŽBENIČKI ODNOSI U LOKALNOJ SAMOUPRAVI - GLAVNI IZVORI PRAVA}

Nakon desetljeća i pol provizorija, tijekom kojeg su se u pogledu položaja lokalnih službenika na odgovarajući način primjenjivali propisi o upravi, ${ }^{13}$ odnosno o državnim službenicima, ${ }^{14}$ krajem prošlog desetljeća započelo je specijalno normiranje ovog područja.

Donesena su dva nova zakona: ZSN i Zakon o plaćama u lokalnoj i područnoj (regionalnoj) samoupravi. ${ }^{15}$ Primjenjuje se i manji dio odredbi ZLPS-a, kao sistemskog zakona kojim je uređena lokalna samouprava. ${ }^{16}$

Što se tiče regulacije plaća, tijekom zakonodavnog postupka postavilo se pitanje u kojoj mjeri platni sustav propisati zakonom, a u kojoj to prepustiti lokalnom reguliranju. Zanimljivo je da su stroži pristup zagovarali naročito neki od sindikata javnih službi, smatrajući da su plaće u lokalnoj samoupravi previsoke. ${ }^{17}$ $\mathrm{Na}$ početku zakonodavne procedure predlagatelj zakona bio je na tragu takve koncepcije (k tome, strože od modela u državnoj službi), ali je u konačnici ipak prihvaćena uravnotežena varijanta. ${ }^{18}$ Tako su Zakonom o plaćama u lokalnoj i područnoj (regionalnoj) samoupravi propisani osnovni elementi za izračun plaće, dopušteni raspon koeficijenata za izračun plaće, te ograničenja mase sredstava za tzv. stimulacije. Ograničen je i udio mase plaća u lokalnom proračunu. Dodatna ograničenja određena su za lokalne jedinice koje u većoj mjeri ovise o financijskoj pomoći države.

Na podzakonskoj razini, Vlada Republike Hrvatske donijela je Uredbu o klasifikaciji radnih mjesta, ${ }^{19}$ pri čemu je klasifikacijski sustav osnova za uređenje platnog sustava (čl. 78. st. 2. ZSN-a).

Predstavničko tijelo lokalne jedinice donosi odluku o ustrojstvu i djelokrugu upravnih tijela, ${ }^{20}$ te odluku o koeficijentima za plaće. Prilikom obračuna plaće, taj se

13 Zakon o upravi (NN 16/78, 50/78, 29/85, 41/90, 47/90, 53/91, 53/91 i 75/93).

14 Zakon o državnim službenicima i namještenicima (NN 27/01).

15 NN 28/10.

16 Radi se, ponajprije, o čl. 53.a i čl. 56. - 56.c ZLPS-a.

U okviru uređenja ustavnog položaja Vlade Republike Hrvatske, odredbom čl. 117. st. 3. Ustava Republike Hrvatske propisano je da se zakonom i drugim propisima uređuje status državnih službenika te radno-pravni status namještenika. U odnosu na lokalne službenike, Ustav ne sadržava analognu normu.

17 Ovdje je korisno spomenuti nešto što izmiče mogućnosti normiranja, a nalazi se prije svega u sferi mentaliteta. Riječ je o iracionalnome negativnom stavu pripadnika nekog od triju prethodno spomenutih vrsta aktera javnog sektora (države, lokalne samouprave, javnih službi) u odnosu na zaposlenike drugih organizacijskih formi - tko je važniji, tko više/manje radi, tko više/manje zarađuje (usporedbe se pritom, naravno, čine s bolje a ne lošije plaćenim segmentima druge skupine) i sl. Kao netko tko je radio i u državnoj i u lokalnoj službi, autor je to iskusio s obiju strana „barikade“.

18 Više o tome v., primjerice, u: Rajko, Alen, ,O prijedlogu Zakona o plaćama u lokalnoj i područnoj (regionalnoj) samoupravi“, Informator, br. 5784-5785/09; Rajko, Alen, „Povodom konačnog prijedloga Zakona o plaćama u lokalnoj i područnoj (regionalnoj) samoupravi“, Ius-Info (www.iusinfo.hr ), 2010.

19 NN 74/10 i 125/14.

20 Čl. 35. t. 4. ZLPS-a. 
koeficijent množi s osnovicom za obračun, koja se određuje kolektivnim ugovorom. Ako takvog ugovora nema, osnovicu određuje izvršno tijelo - tj. općinski načelnik, gradonačelnik ili župan. ${ }^{21}$

Izvršno tijelo ovlašteno je, na prijedlog pročelnikâ upravnih tijela, donijeti pravilnik o unutarnjem redu, opći akt internog karaktera kojim se, prije svega, sistematiziraju radna mjesta i uvjeti za njihovo popunjavanje. Unutar pojedine lokalne jedinice može biti donesen jedan (zajednički) pravilnik, ili više pravilnika, zasebnih za određeno upravno tijelo. ${ }^{22}$

Svi akti koji se donose na lokalnoj razini moraju biti sukladni državnoj legislativi - spomenutim zakonima i Uredbi o klasifikaciji radnih mjesta

\section{POSEBNOSTI STATUSA LOKALNIH SLUŽBENIKA}

Prije svega zbog javnih funkcija koje trajno i profesionalno obavljaju službenici (kao „depozitari vlasti“ - kao što navodi Europski sud za ljudska prava), ${ }^{23}$ pojedina zakonodavstva u većoj ili manjoj mjeri radne odnose u državnoj i lokalnoj službi reguliraju različito u odnosu na zaposlenike u općem radnopravnom režimu. ${ }^{24}$ Upravna efikasnost, naime, i danas u većoj mjeri ovisi o ljudima u upravi negoli o propisima, sredstvima i metodama rada, te drugim faktorima.

\subsection{Dostupnost lokalne službe pod jednakim uvjetima i tzv. merit-sustav}

I lokalna služba obuhvaćena je jamstvom iz članka 44. Ustava Republike Hrvatske (dostupnost javnih službi pod jednakim uvjetima), što razumijeva ulazak u lokalnu službu putem natječaja, uz rijetke iznimke. ${ }^{25} \mathrm{~S}$ druge strane, radni odnosi lokalnih službenika ne ulaze u samoupravni djelokrug lokalnih jedinica, određen primarno odredbama Ustava i Europske povelje. ${ }^{26}$ Indirektno, na položaj lokalnih službenika od utjecaja je dio samoupravnog djelokruga koji se odnosi na autonomiju pri odlučivanju o ustrojstvu lokalne uprave te pri raspolaganju prihodima. ${ }^{27}$

21 Čl. 8. - 10. Zakona o plaćama u lokalnoj i područnoj (regionalnoj) samoupravi.

22 Čl. 4. ZSN-a.

${ }_{23}$ Npr. u predmetu Eskelinen i dr. protiv Finske, zahtjev br. 63235/00, presuda od 19. travnja 2007. , i dr.

24 Među detaljnije domaće analize ove materije pripada: Horvat-Paliska, Snježana, „Državna služba i radni odnosi - sličnosti i razlike“, u: Kuzmić, Marica (ur.), Aktualnosti upravne prakse i upravnog sudovanja - 2016., Inženjerski biro, Zagreb, 2016.

Primarni pravni izvor na području opće regulacije radnih odnosa jest Zakon o radu (NN 93/14).

25 Poput produženja službe vježbeniku na neodređeno vrijeme (čl. 91. ZSN-a).

26 V. npr.: rješenje Ustavnog suda Republike Hrvatske, broj: U-I-1369/2010 od 11. ožujka 2014.; rješenje Ustavnog suda Republike Hrvatske, broj: U-I-6244/2014 od 7. ožujka 2017.; rješenje Ustavnog suda Republike Hrvatske, broj: U-I-3900/2009 od 12. rujna 2017. godine.

27 C̆l. 136. i 138. hrvatskog Ustava; čl. 9. Europske povelje. 
Prema članku 6. stavku 2. Europske povelje, položaj zaposlenih u tijelima lokalnih jedinica treba omogućiti zapošljavanjem osoblja polazeći od načela kakvoće, sposobnosti i stručnosti. U tom cilju osigurat će se odgovarajući uvjeti za njihovo obrazovanje, nagrađivanje i napredovanje. Riječ je o promoviranju tzv. merit-sustava, što se u regulaciji lokalnih službeničkih odnosa prije svega održava putem uređenja institutâ prijma u službu, probnog rada, pojedinih prava i obveza službenika, klasifikacijskog i pravnog sustava, stručnog osposobljavanja i usavršavanja, premještaja, te ocjenjivanja, napredovanja i prednosti pri raspoređivanju kod preustroja. ${ }^{28}$

Među pravima koja pripadnici nacionalnih manjina ostvaruju u dijelu lokalnih jedinica jest i pravo na razmjernu zastupljenost u upravnim tijelima. ${ }^{29}$

\subsection{Službenički odnos: pravni temelj zasnivanja i postupak zaštite, te kolektivno pregovaranje}

Lokalni službenici ne sklapaju ugovor o radu, već se o njihovom prijmu u službu, kretanju u službi, pravima i obvezama, te o prestanku službe odlučuje upravnim aktima. Dosljedno tome, zaštitu prava iz službe ostvaruju u upravnom postupku (primarnom primjenom procesnih odredbi $\mathrm{ZSN}$-a, te podrednom implementacijom Zakona o općem upravnom postupku) ${ }^{30}$ odnosno u upravnom sporu (Zakon o upravnim sporovima). ${ }^{31}$ Od 2017. u državnoj službi su u tom pogledu uvedene određene iznimke, ${ }^{32}$ ali u lokalnoj službi zasad nisu.

Unutar zakonskih okvira, materijalna i druga prava službenika lokalne jedinice mogu biti uređena kolektivnim ugovorom. U dijelu koji nije reguliran normama zakonodavstva na području lokalne službe, niti kolektivnim ugovorom, primjenjuju se opći propisi o radu, prije svega Zakon o radu..$^{33}$

\subsection{Pročelnici upravnih tijela}

Najviše rangirani lokalni službenici jesu pročelnici upravnih tijela. Imenuju se na temelju javnog natječaja, na neodređeno vrijeme, odlukom izvršnog tijela. Osim

28 Više o tome v. primjerice u: Rajko, Alen, „Elementi merit sustava u hrvatskome lokalnom službeničkom zakonodavstvu“, Hrvatska pravna revija, br. 3/09.

Općenito o profesionalizaciji službenika i merit-sustavu v.: Marčetić, op. cit., str. 128-132.

29 Čl. 22. st. 3. i 4. Ustavnog zakona o pravima nacionalnih manjina (NN 155/02, 47/10, 80/10, 93/11, 93/11); čl. 56.a ZLPS-a.

$30 \quad \mathrm{NN} 47 / 09$.

31 NN 20/10, 143/12, 152/14, 94/16 i 29/17.

32 V. čl. 9. Zakona o izmjenama i dopunama Zakona o državnim službenicima (NN 61/17), kojim je izmijenjen tekst čl. 63. Zakona o državnim službenicima. Člankom 63. toga Zakona uređeni su akti što se donose pri odlučivanju o pravima, obvezama i odgovornostima državnih službenika.

33 Čl. 3. st. 2. i 3. ZSN-a. 
što upravljaju tijelima, pročelnici imaju ovlasti prvostupanjskog tijela u upravnim postupcima vezanima uz prava i obveze službenika kojima su nadređeni.

Istodobno, pročelnici su spona s političkim strukturama lokalne jedinice, nalaze se na ključnoj poziciji u onome što se teorijski naziva prijelaznim lancem između političkoga i upravnog pola. ${ }^{34}$ Stoga se ponekad pročelnička mjesta neformalno promatraju kao „politički plijen“ pobjednika lokalnih izbora, unatoč načelnoj profesionalnosti i trajnosti tog položaja.

\subsection{Nadzor}

Unutar lokalne jedinice, rad službenika nadziru pročelnik upravnog tijela te izvršno tijelo jedinice (tj. općinski načelnik, gradonačelnik ili župan). ${ }^{35}$

Kontrolne ovlasti - u segmentu zakonitosti rada - ima i više državnih tijela, osobito upravna inspekcija ${ }^{36}$, te - na području općih akata - uredi državne uprave. ${ }^{37}$

\subsection{Pregled glavnih instituta}

Glavni instituti službeničkih odnosa lokalnih službenika, svojstvene službeničkom statusu, od ulaska u lokalnu službu do napuštanja službeničkog korpusa, jesu: ${ }^{38}$

- prijam u službu,

- raspored na radno mjesto,

- posebni oblici prava i dužnosti, ${ }^{39}$

- odgovornost zbog povrede službene dužnosti (stegovna/ disciplinska odgovornost),

- stručno usavršavanje,

- godišnje ocjenjivanje,

34 O prijelaznom lancu v. npr.: Pusić, Eugen, Hrvatska središnja državna uprava i usporedni upravni sustavi, Školska knjiga, Zagreb, 1997., str. 69; Pusić, Eugen, Nauka o upravi (Knjiga I), Školska knjiga, Zagreb, 1975., str. 73.

${ }_{35}$ Čl. 48. st. 1.t. 3. i čl. 53.a st. 1. ZLPS-a.

36 Čl. 2. i 11. Zakona o upravnoj inspekciji (NN 63/08).

37 Čl. 78. - 82.a ZLPS-a.

38 Dodatna raščlamba ovih instituta, uređenih prije svega odredbama ZSN-a, nerazmjerno bi opteretila ovaj tekst, izlazeći iz okvira njegova cilja.

39 Posebne oblike zaštite službenika čine, primjerice, pravo na zaštitu od prijetnji te kod prijave sumnje na korupciju, odbijanje izvršenja nezakonitih ili neprofesionalnih naloga i dr., dok kao primjer posebnih dužnosti možemo izdvojiti one koje se odnose na sprečavanje sukoba interesa. 
- premještaj i napredovanje,

- položaj kod preustroja upravnih tijela (raspolaganje),

- prestanak službe.

\section{NEKA OTVORENA PITANJA U ZAKONODAVSTVU I PRAKSI}

Radnopravni položaj državnih i lokalnih službenika djelomice se razlikuje. ${ }^{40}$ Pri komparaciji uređenja navedenih dvaju službeničkih sustava, vjerojatno najveći nedostatak regulacije položaja lokalnih službenika jest u tome što u službeničkim predmetima u drugom stupnju upravnog postupka, povodom žalbe službenika, odlučuje izvršno tijelo iste lokalne jedinice. Istodobno, o žalbama državnih službenika odlučuje Odbor za državnu službu, kao specijalizirano, neovisno tijelo. Smatramo da nema pravnih ${ }^{41}$ ni faktičnih zapreka da Odboru, uz promjenu naziva i dodatno kapacitiranje, bude povjerena i uloga drugostupanjskog tijela u odnosu na službeničke odnose u lokalnoj samoupravi.

S druge strane, postoje primjeri u kojima su pojedini normativni modeli koji se primjenjuju u državnoj službi nekritički ,preslikani“ u lokalnu službu, premda u njoj ne mogu biti adekvatni. Riječ je primjerice o normama koje faktički izjednačavaju ministarstva (s nekoliko stotina ili tisuća zaposlenih) s lokalnim upravnim tijelima (koja nerijetko broje tek nekoliko službenika). Kada se takva regulacija pokušava primijeniti na lokalnu razinu, nužno ponekad dolazi do nelogičnosti i smanjene primjenjivosti određenih instituta. ${ }^{42}$

Kao i u državnoj službi, propisani model godišnjeg ocjenjivanja službenika više služi zadovoljavanju forme, negoli stvarnom disktinktiranju službenika različite kvalitete rada i motiviranju boljih službenika. ${ }^{43}$

Prethodno spomenuto izostavljanje dijela radnopravne materije državnih službenika iz domene upravnog prava (izmijenjeni čl. 63. Zakona o državnim službenicima) bilo bi korisno protegnuti i na lokalnu službu.

Nadalje, i unutar sebe, lokalna je samouprava izrazito različita, prije svega po dimenzijama i kapacitetima lokalnih jedinica, ${ }^{44}$ što se održava i na kvalitetu

40 O usporedbi tih dvaju legislativnih sustava v. npr.: Pipunić, Sanda, „Primjena temeljnih instituta Zakona o državnim službenicima i Zakona o službenicima i namještenicima u lokalnoj i područnoj (regionalnoj) samoupravi“, u: Hercigonja, Jasminka - Kuzmić, Marica (ur.), Aktualnosti upravne prakse i upravnog sudovanja, Inženjerski biro, Zagreb, 2015.; Pipunić, Sanda, „Praksa u primjeni propisa službeničkog zakonodavstva“", u: Hercigonja, Jasminka (ur.), Aktualnosti upravne prakse i upravnog sudovanja - 2017., Inženjerski biro, Zagreb, 2017.

${ }^{41}$ Podsjetimo, nije riječ o poslovima iz samoupravnog djelokruga lokalnih jedinica.

42 To je slučaj npr. kod premještaja u drugo upravno tijelo (čl. 98. st. 2. ZSN-a), kod privremenog premještaja (čl. 98.a ZSN-a), te kod raspoređivanja odnosno stavljanja na raspolaganje pri preustroju (čl. 105. st. 3. ZSN-a).

43 Ocjenjivanje lokalnih službenika uređeno je normama čl. 94. - 97. ZSN-a, te odredbama općih akata lokalnih jedinica donesenih na temelju čl. 95. st. 4. ZSN-a.

${ }^{44}$ Ažurni podaci koji ukazuju na spomenute razlike sadržani su, primjerice, u: Jurlina Alibegović, Dubravka, „Porez na nekretnine i mogućnosti financiranja lokalne samouprave“, Informator, br. 6490/17. 
upravljanja lokalnim službenicima, ali i na izglednost privlačenja kompetentnih kadrova.

Kao jedan od načina prevladavanja situacije u kojoj nemali dio lokalnih jedinica nije kapacitiran kvalitetno obavljati poslove iz svojega samoupravnog djelokruga, zakonodavac je predvidio osnivanje zajedničkih upravnih tijela (čl. 54. i 54.a ZLPS-a). Međutim, koliko nam je poznato, ta mogućnost u četvrt stoljeća postojećeg modela lokalne samouprave nije korištena.

Pokušaji političkih utjecaja u sferu upravne autonomije, neovisno o formalnom razgraničenju ovlasti, nisu vezani isključivo uz lokalnu razinu, ali su i u njoj prisutni. Spomenuto nužno rezultira lošijim kadrovskim odabirima, nižom kvalitetom upravnog djelovanja, kao i slabijim povjerenjem javnosti (i) u ovaj segment javnog sektora.

\section{ZAKLJUČAK}

Važnost kvalitete upravnog osoblja i posebnost njegova položaja, te s time povezana specijalna regulacija njegova statusa do izražaja dolazi i na razini lokalne samouprave, kao jednog od glavnih segmenata hrvatskoga javnog sektora. Lokalni službenici čine dio stalnoga, profesionalnog aparata, koncentriranog u upravnim tijelima lokalnih jedinica, načelno podložnog tzv. merit-sustavu. U bitnoj mjeri utječu na ostvarivanje ustavne uloge lokalne samouprave, kao razine ostvarivanja poslova iz samoupravnog djelokruga, te kao jednog od instrumenata ograničenja državne vlasti. Istodobno, sâmi službenički odnosi ne čine dio samoupravnog djelokruga lokalne jedinice.

Po teorijskim podjelama, hrvatski lokalni službenici pripadaju u krug redovnih, pragmatičkih i pravnih službenika.

Regulacija lokalnih službeničkih odnosa obuhvaća posebne zakone o lokalnim službenicima i o plaćama u lokalnoj samoupravi, pojedine odredbe sistemskog zakona o lokalnoj samoupravi, te norme podzakonskih propisa, koji se donose na razini države (klasifikacija radnih mjesta), odnosno lokalne jedinice (unutarnje ustrojstvo i unutarnji red, elementi platnog sustava).

Lokalna služba obuhvaćena je ustavnim jamstvom na dostupnost javnih službi pod jednakim uvjetima. Prijam u službu i odlučivanje o pravima, obvezama i odgovornostima službenika u režimu je upravnih akata i upravnog postupka, uz sudsku zaštitu putem upravnog spora. Pored toga, više je posebnih službeničkopravnih instituta, po kojima se (lokalna) služba razlikuje od općeg režima radnih donosa.

Lokalna i državna služba imaju veći broj zajedničkih odrednica, uz poneke razlike, koje se u mjerodavnoj legislativi ne uzimaju uvijek u obzir. U odnosu na državnu službu, uređenje lokalne službe u najvećoj je mjeri supstandardno u pogledu zaštite prava službenike u žalbenom postupku. Vjerujemo da bi bilo svrhovito sastaviti generalni službeničkopravni zakon, s ujednačenom regulacijom 
instituta koji su na jednaki način svojstveni državnoj i lokalnoj službi, uz dodatne odredbe kojima bi bila uređena materija vezano uz koju postoje razlike između navedenih službeničkih sustava.

Službenički sloj, mada načelno profesionalan, stalan i nepodložan političkim promjenama, ni na lokalnoj razini nije lišen političkih utjecaja koji prelaze granice usmjeravanja i nadzora uprave od strane političkih tijela. Spomenuto smanjuje kvalitetu upravnog djelovanja, te nagriza povjerenje javnosti u lokalnu samoupravu.

\section{CIVIL SERVICE SYSTEM IN LOCAL AND REGIONAL SELF- GOVERNMENT IN CROATIA - REGULATION AND OPEN QUESTIONS}

The main elements of the civil service system in the Croatian local and regional self-government were analyzed, in the context of the position of local self-government in the public sector as a whole, the position of administrative bodies in the structure of local units, as well as the status of local civil servants in relation to the entire civil servants' corps and the general labour law regime. Besides, related open questions in the relevant legislation and in practice were pointed out.

Key words: civil servants, civil service system, local and regional self-government 